\title{
Changing Rationales for the Internationalization of Higher Education
}

\section{Hans de Wit}

Hans de Wit is vice president for international affairs, at the University of Amsterdam. Address: University of Amsterdam, POB 19268, 1000 GG Amsterdam, The Netherlands.

I nternationalization is high on the agendas of national 1 governments, international bodies, and institutions of higher education. Might this be the beginning of a revival of the medieval cosmopolitan university, within the context of a new age, in which the society, the economy, and knowledge itself are part of a global environment? However, the time when universities could hide within their ivory towers are far behind us. Subsequently, higher education came to serve the administrative and economic interests of the nation-states, becoming essential in the development of national identity. The scholar evolved from a cosmopolitan wanderer into a citizen. But toward the end of this century, learning has again become more international. Not only are nations and international bodies placing greater emphasis on international cooperation and exchange, but the institutions themselves are developing their own strategies to internationalize research and teaching.

\section{A Working Definition}

In the course of a comparative study, Jane Knight and I arrived at the following working definition: "Internationalisation of higher education is the process of integrating an international/intercultural dimension into the teaching, research and service functions of the institution." This definition understands internationalization as a process, as a response to globalization (not to be confused with the globalization process itself), and as including both international and local elements.

This way of looking at the internationalization of higher education differs quite a bit from many other approaches to this theme. In most cases, the internationalization of higher education is reduced to just a few activities-such as academic mobility, global or multicultural education, area studies, and study abroad. But this is to confuse internationalization with various rationales-political ones, like peace and mutual understanding; or economic ones, like the needs of an ever more international labor market. Most studies ignore the links between the international and the local environment. Finally, such studies see internationalization not as a process but as an activity with a beginning and an end.

\section{Rationales}

The role and the character of the political and economic rationales for internationalization of higher education have changed more radically over time. For example, in the European medieval university and in the Arab university even earlier, academic and social/cultural rationales for internationalization were dominant: the wandering scholar looking for knowledge and an understanding of other cultures.

Why are institutions of higher education, national governments, international bodies, and (increasingly) the private sector-banks, industry, and foundations-now so actively involved in international educational activities? There is no single answer to this question. Rather, four kinds of rationales can be seen: academic, social/cultural, political, and economic. ${ }^{2}$ Moreover, when analyzing rationales, we have to take into account the diverse stakeholder groups within higher education: government, private, and educational sectors.

Political rationales. As the nation-state developed and with it colonial expansion, political rationales came to the fore. By replicating European models of higher education in their colonies in the Americas, Africa, and Asia, the European nations were looking for political, cultural, economic, and academic dominance-a dominance that continues to be an issue today.

With the rise of the United States as an international power in this century, and in particular after World War II, this political rationale took on a new dimension. In the drive to maintain and expand America's influence, knowledge of other cultures, languages, and systems, became critically important. Universities in the United States were stimulated with federal funding, mainly through the State and Defence Departments, to develop area studies, foreign-language training, and study abroad programs. Although seen by many in the rest of the world as a sign of American imperialism-matched by a similar trend in the former Soviet Union-it was presented by U.S. policymakers as an initiative for peace and mutual understanding.

\section{Since World War II, the political ratio- nale has been the dominant one in ini- tiatives to internationalize higher education. But with the end of the Cold War, the emphasis has changed from the political to the economic.}

This optimistic view of international education as a force for peace has been a dominant one in American politics and higher education over the past 50 years and has found supporters elsewhere. While it is quite tempting to sympathize with this view, such a political rationale for in- 
ternationalization should raise a number of questions: Who's concept of peace and who's understanding of the world would be served? Have higher education systems in the rest of the world ever been in the position to promote their own understanding of these issues on equal terms with the American and European academic world? Does the dominant view of internationalization provide space for national identity?

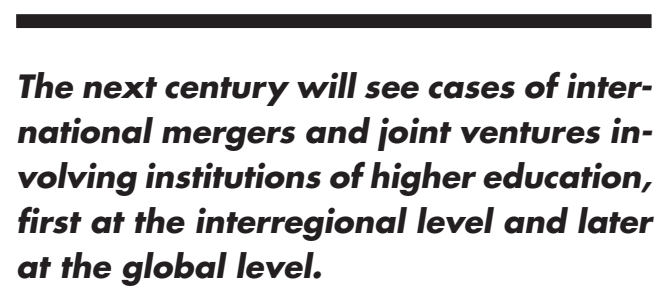

A comparative study of internationalization strategies in Asian Pacific countries, showed a focus not so much on global identity as on national identity. By becoming part of a global environment on more equal terms, higher education and society as a whole can move away from dependency and the dominance of Western technology, Western methods, and Western languages of instruction. This strategy would not involve the expansion of English as the language of instruction-something that has become an issue in several higher education institutions in continental Europe. The option of promoting local languages of instruction-to replace the colonial, mainly English, language-is an international strategic consideration in several Asian universities and countries. The local or national impact of internationalization is of less concern in Europe and the United States, where globalization and uniformity seem the dominant perspectives.

Since World War II, the political rationale has been the dominant one in initiatives to internationalize higher education. But with the end of the Cold War, the emphasis has changed from the political to the economic.

Economic Rationales. Economic rationales were and still are the driving force behind European programs for cooperation and exchange in research, technology, and education-such as the research and development programs, COMETT and ERASMUS. These programs contain the additional political rationale of stimulating the development of a European citizenship.

This change in emphasis from the political to the economic, is demonstrated in a 1997 study, "National Policies for the Internationalisation of Higher Education in Europe," carried out by the Swedish National Agency for Higher Education. For the Scandinavian countries, Austria, Germany, the United Kingdom, and the Netherlands, as well as in Central and Eastern Europe, the findings in- dicate a tendency to shift from educational, cultural, and political factors to economic factors as the dominant rationale for internationalization. The only exception was in southern Europe (e.g., Greece), where the internationalization of higher education is still more driven by traditional academic, cultural, and political rationales.

Economic rationales are expressed in several ways: an emphasis on internationalization to meet the demands for a modern, more global labor force; joint international R\&D projects to be competitive in the new technologies; and greater focus on marketing higher education internationally_viewing higher education as an export commodity.

\section{The International University}

The political and economic rationales that are currently pushing higher education institutions to beocme more international are mainly factors external to those institutions. This does not mean that universities have no internal incentive to become more international. The academic environment itself has changed radically in the past 50 years. Higher education has become more deregulated, privatized, and market oriented, with more diverse income sources. The entrepreneurial university of today has its own reasons to become more international once again. The recent emphasis on professional education, on continuous education, and on new areas such as environmental studies and information science requires a comparative and international dimension. Demand for this emphasis comes not only from outside the institution but also from faculty and students.

Can we expect, in the coming century, that universities will finally embark on the same path as have banks, industry, and even countries in the past: that is, move into joint ventures, merge across borders, and share their human recourses? This course would seem a logical, unavoidable step, but it has not yet been fully addressed by higher education institutions.

The next century will see cases of international mergers and joint ventures involving institutions of higher education, first at the interregional level (for instance, in the European Union) and later at the global level. At the same time, more and more faculties and schools will combine efforts in consortia, beyond such institutional mergers and joint ventures.

\section{Notes}

This article is a shorter version of a paper presented at the EAIE conference in Stockholm, 22-24 November 1998. The full text will be part of a planned publication by CEPES/UNESCO in 1999.

1. Jane Knight and Hans de Wit, Internationalisation of Higher Education in Asia Pacific Countries (Amsterdam: EAIE, 1997), 8.

2. Hans de Wit, Strategies for Internationalisation of Higher Education, A Comparative Study of Australia, Canada, Europe and the United States of America (Amsterdam: EAIE, 1995), 9-14. 